\title{
RAGAM HIAS DAN FUNGSI BATIK MINANG NAGARI PANYAKALAN KABUPATEN SOLOK
}

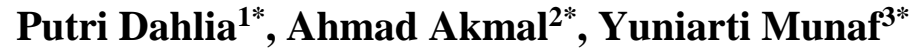 \\ Minat Pengkajian Seni Kriya Program Pascasarjana \\ Institut Seni Indonesia Padangpanjang \\ Jl. Bahder Johan, Guguak Malintang, Padangpanjang, Kota Padangpanjang, 27126. \\ Sumatera Barat. Indonesia. \\ Email: putrydahlia0101@gmail.com
}

\begin{abstract}
Abstrak
Penelitian ini berjudul "Ragam Hias dan Fungsi Batik Minang Nagari Panyakalan Kabupaten Solok", membahas tentang bentuk motif dan fungsi batik Minang, serta dampak yang ditimbulkan dengan adanya batik tersebut terhadap masyarakat. Sebagai produk budaya, batik Minang mempunyai nilai strategis dalam sistem budaya dan perekonomian sebagian masyarakat. Nilai budaya dan filosofi yang dikandung dipahami melalui simbol berupa motif hias pada batik. Penelitian ini menggunakan metode kualitatif. Teori estetis Edmund Burke Feldman menyangkut struktur, gaya, dan fungsi karya seni, digunakan dalam pembahasan mengenai Batik Minang. Feldman membagi fungsi seni menjadi tiga bagian, yaitu fungsi personal (personal function of art), fungsi sosial (social function of art) dan fungsi fisik (physical function of art). Perkembangan batik Minang dewasa ini cenderung dipengaruhi aspek ekonomi dan sosial budaya. Begitu pula sistem keahlian dilakukan melalui pengembangan terhadap produk yang lebih kreatif dan variatif dalam bentuk maupun fungsi. Hal ini menjadi salah satu faktor penopang keberlangsungan seni batik Minang ini. Di era global ini batik Minang dikembangkan dan dimanfaatkan sebagai unsur estetik modern dengan maksud memberi nuansa eksotisme suatu penampilan, beberapa di antaranya berkembang menjadi produk industri seni sebagai material kebutuhan dan permintaan konsumen luar Provinsi
\end{abstract}

Kata Kunci: Batik Minang, Fungsi, Estetika, Panyakalan

\begin{abstract}
This research entitled "Decorative and Function Batik Minang in Panyakalan Solok Regency", discusses the form of motif contained in batik Minang art, and the impact that arises with the art of batik on society. As a cultural product, Minang batik art also has strategic value in cultural system and economy of some society. The value of culture and philosophy conceived through the symbol of decorative motifs on this batik art. This research uses qualitative method. Aestetic theory Edmund Burke Feldman about the structure, style, and function of artwork, used in the discussion of batik Minang. Feldman devides the function into three parts, that is personal function of art, fungsi sosial the social function of art, and physical function of art. The development of batik Minang today tend to be influenced by economic and socio-cultural aspects. Similarly, system expertise is done through the development of products that are more creative and varied in form and function. This became one of the factors supporting the continuity of batik Minang art. In this global era batik Minang is developed and utilized as an aesthetic element of modern interior with the intention to give feel of exoticism an appearance, some of which developed into art industry product as material requirement and demand offoreign consumer.
\end{abstract}

Keywords: Batik Minang, Function, Aesthetic, Panyakalan

\section{PENDAHULUAN}

Seni batik adalah salah satu kesenian khas Indonesia yang telah sejak berabad-abad lamanya hidup dan berkembang, sehingga merupakan salah satu bukti peninggalan sejarah budaya bangsa Indonesia. Membatik pada dasarnya sama dengan melukis di atas sehelai kain putih. Sebagai alat melukis dipakai canting dan sebagai bahan melukis dipakai cairan malam (Nian, 1990:1). Sumatera Barat sudah sejak lama dikenal sebagai salah satu daerah penghasil karya seni kerajinan tangan yang beragam, mulai dari ukiran, gerabah, sulaman, tenun, bordir dan lain-lain. Melalui kerajinan tangan ini, ragam hias Minangkabau diperkenalkan kepada khalayak luas melalui berbagai produk kriya yang akrab dengan kehidupan seharihari, seperti ornamen yang terdapat pada bangunan, pakaian, dan alat-alat rumah tangga.

Ragam hias Minangkabau semakin diperkenalkan melalui seni kerajinan batik yang tengah digiatkan di 


\section{Gorga Jurnal Seni Rupa \\ Volume 07 Nomor 02 \\ p-ISSN: 2301-5942 | e-ISSN: 2580-2380}

berbagai daerah di Sumatera Barat. Salah satu penggiat kerajinan batik ini adalah Rumah Batik Minang yang berlokasi di Jorong Pakansabtu Nagari Panyakalan Kecamatan Kubung Kabupaten Solok. Sebelum adanya rumah batik Minang ini, ternyata dahulu tanah Minangkabau sudah memiliki seni batik yang dikenal dengan batik tanah liek / tanah liat. Dinamakan batik tanah liek karena pembuatan batik menggunakan pewarnaan dari alam, yaitu tanah liat (Yanuarmi, 2011:1).

Batik sebagai sebuah karya seni merupakan karya yang tumbuh secara universal dengan karakteristik dan corak yang khas serta memiliki ciri tersendiri. Kekhasan batik dipandang sebagai salah satu budaya asli daerah tempat ia tumbuh. Sebagai salah satu seni tradisional, batik menyimpan konsep artistik yang dibuat tidak hanya untuk keindahan tetapi juga berfungsi sebagai pilihan busana sehari-hari, untuk keperluan upacara adat, tradisi, kepercayaan, agama dan status sosial (Aep, 2010).

Sebutan batik Minang pada sentra industri Rumah Batik Minang Nagari Panyakalan ini tidak terlepas dari bentuk motif yang diterapkan. Keberagaman motif Minangkabau menjadi pembeda batik Minang dengan batik lain yang ada di Indonesia. Alam memberikan pengaruh yang besar dalam terciptanya karya seni yang memiliki karakteristik, terutama dapat dilihat dari bentuk motif yang diterapkan.

Ragam hias hadir di tengah-tengah masyarakat sebagai media ungkapan perasaan yang diwujudkan dalam bentuk visual, yang proses penciptaannya tidak terlepas dari pengaruh lingkungan. Hal di atas sesuai dengan yang dikemukakan oleh Nian S. Djoemena bahwa hasil lukisan atau ragam hias batik sangat erat hubungannya dengan beberapa faktor, seperti; letak geografis daerah pembuat batik, sifat dan tata penghidupan daerah yang bersangkutan, kepercayaan dan adat istiadat setempat, keadaan alam sekitarnya, termasuk flora dan fauna, serta adanya kontak atau hubungan antar daerah pembatikan (1990:1). Tidak terlepas dari falsafah adat Minangkabau "alam takambang jadi guru", bahwa alam tidak hanya sebagai tempat lahir dan tempat mati, tempat hidup dan berkembang, tetapi juga memiliki makna filosofis yang diambil dari bentuk, sifat, dan kehidupan alam (Navis, 1984:59).

Batik Minang Nagari Panayakalan dikembangkan dan dimanfaatkan sebagai unsur estetik modern dengan maksud memberi nuansa eksotisme suatu penampilan, beberapa diantaranya berkembang menjadi produk industri seni sebagai material kebutuhan dan permintaan konsumen luar Propinsi. Sudah tentu kontinuitas dan perubahan seni kriya yang mengandung nilai luhur budaya bangsa akan tetap terpelihara dengan baik apabila usaha pengembangannya didasarkan atas pemikiran yang rasional. Kepekatan cita rasa estetik yang mendalam, dan keyakinan iman yang kuat.

Sehubungan dengan penulisan ini, segala hal yang berkaitan dengan persoalan Seni Batik Minang Panyakalan didefinisikan sebanyak mungkin untuk memperoleh data-data, baik yang berhubungan dengan kerajinan batik sebagai objek pokok maupun perajin sebagai objek pendukungnya.

\section{KAJIAN TEORI}

Memudahkan dalam menganalisis dan menjawab permasalahan ragam hias dan fungsi batik Minang Nagari Panyakalan digunakan pendekatan fungsi. Feldman dalam Gustami menjelaskan tentang fungsifungsi seni yang sudah berlangsung sejak zaman dahulu, diantaranya adalah untuk memuaskan: (1) kebutuhan-kebutuhan individu kita tentang ekspresi pribadi (personal function of art), (2) kebutuhankebutuhan sosial kita untuk keperluan display, parayaan dan komunikasi, (social function of art), serta (3) kebutuhan-kebutuhan fisik kita mengenai barang-barang dan bangunan yang bermanfaat (physical function of art) (1991:2).

\section{METODE PENCIPTAAN}

Penelitian ini menggunakan metode penelitian kualitatif interaktif untuk mencari data-data dan fakta yang terdapat pada objek penelitian secara objektif dan ilmiah. Moleong (2004:6), mengemukakan bahwa penelitian kualitatif adalah penelitian yang dimaksud untuk memahami fenomena tentang apa yang dialami oleh subjek penelitian misalnya perilaku, persepsi, motivasi, tindakan secara holistik, mendeskripsi dalam bentuk kata-kata dan bahasa pada suatu konteks alamiah dengan memanfaatkan berbagai metode ilmiah.

Data dapat digali dari sumber tulisan, lisan dan sumber visual yang terekam dalam konteks yang berbeda. Salah satu sifat dari data itu merupakan data yang memiliki kandungan yang kaya, multidimensional dan kompleks.

\section{Lokasi Penelitian}

Penelitian dilakukan pada sentra industri Rumah Batik Minang yang berlokasi di Jorong Pakansabtu Nagari Panyakalan Kecamatan Kubung Kabupaten Solok 


\section{Gorga Jurnal Seni Rupa \\ Volume 07 Nomor 02 \\ p-ISSN: 2301-5942 | e-ISSN: 2580-2380}

Sumatera Barat. Rumah Batik Minang ini merupakan salah satu sentra industri penghasil kerajinan batik yang tengah berkembang di Sumatera Barat.

\section{Sumber Data}

Sumber data yang dimanfaatkan dalam penelitian ini sebagai berikut:

1).Data Primer adalah data yang diperoleh langsung dari sumbernya. Sumber data primer yang digunakan dalam penelitian ini meliputi sentra industri Rumah Batik Minang Nagari Panyakalan dan informasi dari para perajin, pengguna, serta pakar dari batik Minang Nagari Panyakalan.

2).Data Sekunder adalah data yang diperoleh bukan secara langsung dari sumbernya. Penelitian ini sumber data sekunder yang dipakai adalah sumber tertulis seperti sumber buku, majalah ilmiah, dan dokumendokumen dari pihak yang terkait mengenai batik Minang Nagari Panyakalan.

\section{Teknik Pengumpulan Data}

\section{1).Studi Pustaka}

Studi pustaka dilakukan untuk memperoleh informasi tertulis dari referensi yang ada. Referensi yang dimaksud adalah berhubungan dengan objek penelitian, baik berupa buku cetak, laporan penelitian, makalah, jurnal dan tulisan-tulisan yang terdapat di media komunikasi tulis lainnya.

Studi pustaka bertujuan untuk melihat apakah sudah ada penelitian yang sama sebelumnya, selain itu melihat dasar teori yang digunakan dalam penulisan kajian. Buku dan laporan penelitian yang menjadi referensi, dapat mengarahkan pola pikir penulis dalam melakukan penelitian. Berdasarkan studi pustaka, pambahasan lebih relevan tentang objek penelitian.

Kepustakaan yang menunjang untuk kajian penelitian ini adalah pustaka pusat ISI Padangpanjang dan pustaka Pascasarjana ISI Padangpanjang yang mengkoleksi buku-buku yang terkait dengan objek penelitian, selain itu juga digunakan artikel-artikel tentang Rumah Batik Minang Nagari Panyakalan.

\section{2).Observasi}

Observasi merupakan salah satu teknik yang akan digunakan dalam pengumpulan data. Nasution dalam Sugiono (2008:226), menyatakan bahwa observasi adalah dasar semua ilmu pengetahuan. Para ilmuwan hanya dapat bekerja berdasarkan data, yaitu fakta mengenai dunia nyata yang diperoleh melalui observasi. Kajian mengenai ragam hias dan fungsi batik Minang Panyakalan, menggunakan teknik observasi terus terang atau tersamar. Peneliti dalam melakukan pengumpulan data menyatakan terus terang kepada sumber data, bahwa peneliti akan melakukan penelitian. Peneliti melakukan kajiankajian untuk dapat berinteraksi dengan narasumber dalam rangka mendapatkan data yang valid. Tempat pembuatan batik merupakan lokasi pertama untuk memperoleh data yang berkaitan dengan batik Minang.

Perajin dan pengusaha menjadi sasaran utama observasi terhadap struktur dan bentuk batik. Dari pengamatan langsung didapatkan data visual tentang hasil produk batik, bagaimana bentuk ragam hias yang menjadi ciri khas batik tersebut.

\section{3).Wawancara}

Wawancara merupakan salah satu teknik pengumpulan data kepada informan yang terlibat sebagai subjek penelitian. Esterberg dalam Sugiono (2008:233), mengemukakan beberapa macam wawancara, yaitu: wawancara tersutruktur, semitersutruktur, dan tidak terstuktur.

Wawancara terstruktur (structured interview), dilakukan dengan mempersiapkan daftar pertanyaan untuk membantu lancarnya pertanyaan dalam proses tanya jawab. Teknik kedua yaitu wawancara semiterstruktur (semistructure interview), wawancara jenis ini lebih bebas dari pada wawancara terstruktur yang bertujuan untuk menemukan permasalahan secara lebih terbuka. Selanjutnya adalah wawancara tidak terstruktur (unstructured interview), yaitu wawancara bebas, dimana peneliti tidak menggunakan pedoman wawancara yang telah tersusun secara sistematis dan lengkap untuk pengumpulan datanya.

Wawancara teknis dilakukan kepada perajin batik Minang di Nagari Panyakalan, sedangkan permasalahan non teknis dilakukan tanya jawab kepada pengguna dan pihak yang punya andil dalam pelestarian batik di Rumah Batik Minang Nagari Panyakalan. Wawancara menjadi salah satu teknik pengumpulan data terhadap responden yang terlibat sebagai objek penelitian. Ia menjadi teknik komunikasi secara langsung antara peneliti dengan objek atau sampel. Keberhasilan teknik wawancara sangat bergantung pada suasana yang dibangun dengan informan yang diwawancarai sehingga komunikasi akan berjalan dengan baik.

\section{4).Dokumentasi}

Dokumentasi adalah pengambilan data yang diperoleh melalui dokumen-dokumen. Dokumen bisa berbentuk tulisan, gambar, atau karya-karya monumental dari 


\section{Gorga Jurnal Seni Rupa \\ Volume 07 Nomor 02 \\ p-ISSN: 2301-5942 | e-ISSN: 2580-2380}

seseorang. Data-data yang dikumpulkan dengan teknik dokumentasi cenderung merupakan data sekunder (seperti foto-foto), sedangkan data-data yang dikumpulkan dengan teknik observasi, wawancara cenderung merupakan data primer (data yang langsung didapat dari pihak pertama) (Muri, 2005:173). Objek penelitian tentang batik Minang di Nagari Panyakalan ini akan didokumentasikan dalam bentuk tulisan, foto maupun video.

\section{Teknik Analisis Data}

Bogdan dalam Sugiono (2008:244), mendefinisikan analisis data sebagai upaya mencari dan menyusun secara sistematis data yang diperoleh dari hasil wawancara, catatan lapangan, dan bahan-bahan lain, sehingga dapat dengan mudah dipahami dan temuannya dapat diinformasikan. Penelitian ini menggunakan teknik analisis data yang mengacu pada Miles dan Huberman sebagaimana dikutip dalam Sugiono (2008:246), bahwa aktifitas dalam analisis data kualitatif dilakukan secara interaktif dan berlangsung secara terus menerus sampai tuntas.

Data yang terkumpul diolah, diseleksi dan diklasifikasikan berdasarkan bobot permasalahan, lalu dicari hubungan atau bandingan dengan data pustaka. Selanjutnya menyeleksi dan memadukannya sehingga menjadi fakta-fakta yang dapat dipertanggungjawabkan. Kemudian dilakukan analisis dengan cara menginterpretasikan. Data-data yang diperoleh dari studi kepustakaan, observasi, dan wawancara dianalisis dengan menggunakan teori dan konsep yang relevan dengan penelitian. Hasil dari tahap analisis akan menjadi temuan penting yang akan menjadi hasil akhir dari keseluruhan tahapan penelitian. Keabsahan data atau validnya data merupakan tanggungjawab ilmiah yang perlu diutamakan dalam penelitian.

\section{HASIL DAN PEMBAHASAN}

\section{Ragam Hias Batik Minang Nagari Panyakalan}

Ragam hias pada batik terjadi karena perbedaan latar belakang yang mendasari terciptanya kain batik, seperti adat istiadat, gaya hidup masyarakat, serta lingkungan alam setempat. Ragam hias seni batik Minang ditujukan sebagai pelengkap rasa estetis. Pada bentuk ragam hias yang ada, terdapat makna simbolik tertentu menurut yang berlaku secara konvensional di lingkingan masyarakat pendukungnya (Toekio, 1984). Penciptaan ragam hias seni batik Minang terlihat pada kepekaan dan ketelitian perajin membuat kain batik. Ragam hias dengan beberapa bentuk motif dibuat sesuai dengan bentuk yang telah ada.
Kesatuan ragam hias secara keseluruhan merupakan perpaduan unsur garis yang harmonis. Apabila dilihat secara sepintas, tidak begitu jelas bentuk gambar apa yang dipadu membentuk satu kesatuan motif hias. Apabila diamati secara seksama, akan terlihat bentukbentuk dari alam yang dihadirkan ke dalam lembar kain batik. Bentuk yang dijadikan ragam hias bagi masyarakat Minangkabau, selain bermanfaat untuk keindahan juga mengandung arti dan makna yang diterapkan dalam sendi kehidupan.

Penempatan ragam hias seni batik Minang tidak menjadi aturan yang baku, namun tetap menghadirkan bentuk motif yang menjadi karakteristik batik. Ragam hias batik merupakan pengulangan dari bentuk motif yang sudah ada. Pengulangan-pengulangan tersebut dilakukan sesuai dengan desain dari seniman, perajin, pengusaha maupun permintaan konsumen (Wawancara, Roza (40th) 13 November 2017, Nagari Panyakalan).

Ragam hias atau ornamentasi yang diterapkan pada seni kerajinan batik Minang di Panyakalan, mengambil bentuk dari alam berupa ragam hias tumbuh-tumbuhan dan binatang. Latar belakang etnografis, luasnya hamparan sawah di Kabupaten Solok menandakan kakayaan alam yang dimiliki. Alam yang indah memunculkan bentuk ragam hias, baik bentuk tumbuhan ataupun bentuk hewan yang ada di dalamnya. Diantaranya motif kaluak paku, pucuak rabuang, limpapeh rumah gadang, aka cino saganggang, si kambang manih, ruso balari dalam rangsang, ayam mancotok dalam kandang, dan masih banyak motif Minangkabau lainnya. Selain itu kerajinan batik Minang Nagari Panyakalan memiliki ciri khas motif daerah Kabupaten Solok, seperti: motif rumah gadang, markisa dan batang padi.

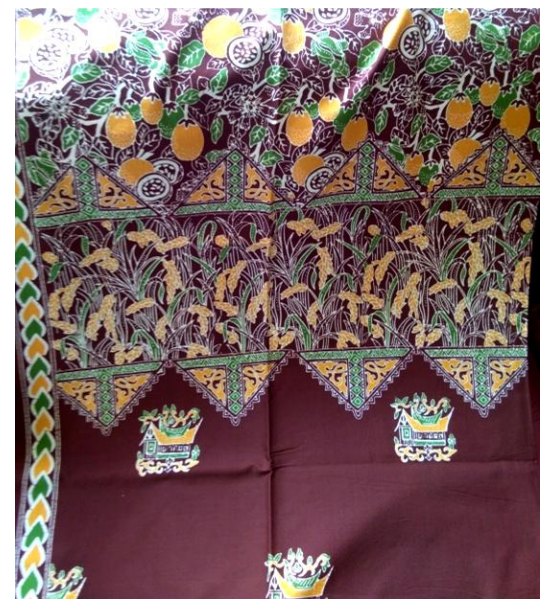

Gambar 1. Motif Rumah Gadang, Markisah dan Batang Padi 


\section{Gorga Jurnal Seni Rupa \\ Volume 07 Nomor 02 \\ p-ISSN: 2301-5942 | e-ISSN: 2580-2380}

Gambar di atas merupakan salah satu ciri khas motif yang terdapat pada seni batik Minang Nagari Panyakalan. Motif ini diilhami dari keinginan penggiat batik Minang untuk menganggat hasil kekayaan alam daerah Kabupaten Solok. Pemilihan motif batang padi diciptakan karena Kabupaten Solok merupakan penghasil beras (bareh Solok) yang berkualitas baik di Sumatera Barat. Pemilihan motif Rumah Gadang diilhami dari adat istiadat dan kebudayaan Minangkabau yang memiliki rumah adat bagonjong yakni Rumah Gadang. Motif markisa diilhami dari hasil perkebunan markisa milik masyarakat Kabupaten Solok tepatnya di wilayah Alahan Panjang, Air Dingin dan Danau Kembar. Daerah tersebut menghasilkan buah markisa terbaik di Sumatera Barat dan menjadi maskot Kabupaten Solok. Hal ini dibuktikan dengan adanya gapura patung markisa di perbatasan Kota Solok dengan Kota Padang. Berdasarkan hal tersebut Rumah Batik Minang memproduksi batik dengan motif buah markisa (Wawancara, Roza (40th) 13 November 2017, Panyakalan Kabupaten Solok).

\section{Gaya Seni Batik Minang Nagari Panyakalan}

Gaya adalah sebuah kekhasan (distinctive) atau identitas, identifikasi (identifiable) dari bentuk (form) pada medium artistik. Dalam bahasa Inggris gaya disebut dengan style yang berarti corak dan mode. Dapat dipahami bahwa suatu karya seni memiliki berbagai macam gaya, dimana gaya seni tersebut dapat dipahami dalam konteks budaya dan sejarah sosial (Nasbahry, 2002:165).

Agus Sachari menjelaskan bahwa gaya seni akan dipengaruhi oleh zaman. Secara umum, tumbuhnya keragaman gaya pada dunia desain dan seni rupa terbentuk oleh pengaruh kebudayaan yang berkembang saat itu. Namun aspek maknawi tetap merupakan suatu proses penyadaran, bahwa nilai-nilai estetik menjadi bagian penting dalam proses transformasi budaya (2002:127-129). Soedarso SP, menilai suatu gaya, corak atau langgam yang disejajarkan dengan istilah style adalah modus berekspresi dalam mengutarakan sesuatu bentuk. Artinya gaya, corak, atau langgam ini berurusan dengan bentuk luar sesuatu karya seni (2006:85).

Berdasarkan beberapa uraian di atas, dapat dikatakan bahwa seni batik di Minangkabau merupakan produk budaya tradisional, yang sudah lama ada. Perwujudannya diawali dengan proses keterampilan para perajin, dengan kekriyaan yang tinggi serta bernilai guna. Hasil dari batik tidak terbatas pada keperluan untuk acara adat dan tradisi lainnya, seperti pada awal penciptaannya.
Gaya seni batik dapat dilihat dari bentuk yang ditampilkan, baik berupa ragam hias yang diterapkan maupun warna yang digunakan. Batik berupa produk seni kerajinan yang kental dengan corak tradisional, memiliki karakter yang khas. Ragam hias tradisional Minangkabau yang diterapkan tetap dipertahankan dan tidak mengalami perubahan meskipun bentuk dan fungsi mulai berkembang. Ragam hias dengan bentuk yang unik dan khas pada berbagai macam produk, tetap mengandung filosofi yang sama.

Makna yang terkandung dari ragam hias yang ditampilkan sesuai dengan falsafah hidup masyarakat pendukungnya. Ragam hias tradisional yang digunakan menunjukkan kemampuan perajin dalam kreatifitas menciptakan ragam hias. Diilhami dari bentuk-bentuk yang ada di alam, bentuk flora dan fauna yang terdapapat pada alam Kabupaten Solok digambarkan secara dekoratif dan geometris.

Batik Minang Nagari Panyakalan memiliki beberapa motif yang ditampilkan sehingga membentuk satu kesatuan, baik untuk pembuatan produk perangkat adat maupun untuk produk fungsional lainnya. Pengembangan ragam hias batik tidak menutup kemungkinan mengalami perubahan, seperti warna yang digunakan. Namun perubahan yang dilakukan tidak menghilangkan ciri dan karakteristik batik Minang sebagai produk budaya. Perubahan yang dilakukan adalah dari segi penempatan motif dan pengurangan-pengurangan pada bagian tertentu, sehingga batik tetap bisa dikenali dan dipandang sebagai produk budaya yang kreatif dan inovatif.

\section{Fungsi Batik Minang Nagari Panyakalan}

Batik mampu bertahan hingga sekarang karena fungsinya yang selalu mengikuti perkembangan zaman dan kebutuhan pasar. Keberadaan sentra industri batik dijadikan sebagai ajang memperkenalkan kebudayaan setempat kepada khalayak luas melalui beragam bentuk dan fungsi produk batik. Batik di Minangkabau dahulunya digunakan untuk keperluan tertentu sebagai pelengkap pakaian pada upacara-upacara adat, seperti batagak panghulu. Pada acara tersebut, batik pada pakaian panghulu terdapat pada saluak yang digunakan, sedangkan pada pakaian bundo kanduang batik dapat dijumpai pada pakaian selendang / sisampiang. Melihat kondisi tersebut, produksi batik tidak begitu menjanjikan untuk dijadikan sebagai mata pencaharian para perajin, sehingga dikembangkan produk batik menjadi lebih kompleks mengikuti selera zaman. 


\section{Gorga Jurnal Seni Rupa \\ Volume 07 Nomor 02 \\ p-ISSN: 2301-5942 | e-ISSN: 2580-2380}

Batik berkaitan dengan aktivitas pembuatan kain yang memiliki tingkat kerumitan dan kehalusan ragam hiasnya. Aspek batik sebagai pelengkap pakaian tradisional, tetap dipertahankan meskipun dewasa ini perkembangan fungsi semakin menampakkan wujudnya. Batik tidak saja untuk pelengkap pakaian tradisional, yaitu untuk kelengkapan upacara adat, tetapi berkembang menjadi produk yang lebih variatif (Anas, 1997:10-11). Dengan begitu kelangsungan batik tetap bertahan dan tetap dikonsumsi masyarakat luas, tidak hanya kalangan tertentu saja. Seperti yang diungkapkan Gustami:

Formulasi bentuk, makna, perwujudan dan fungsi karya seni terkait erat dengan fonomena sosial, politik, ekonomi, budaya dan agama yang berkembang di masyarakat, karena mereka adalah eksponen pembentuk yang memiliki seperangkat uniform. Kehadiran karya seni juga dipengaruhi oleh kondisi lingkungan alam sekitarnya, karena kecuali lingkungan alam menyediakan bahan baku bagi aktifitas hidup dan penciptaan seni, alam juga dapat menjadi sumber ide yang menyadarkan manusia atas kebesaran kuasa Tuhan, sekaligus menjadi pendorong tersalurnya kegiatan kreatif secara menyeluruh (2007:233).

Feldman dalam Gustami menjelaskan tentang fungsifungsi seni yang sudah berlangsung sejak zaman dahulu, diantaranya adalah untuk memuaskan: (1) kebutuhan-kebutuhan individu kita tentang ekspresi pribadi (personal function of art), (2) kebutuhankebutuhan sosial kita untuk keperluan display, parayaan dan komunikasi, (social function of art), serta (3) kebutuhan-kebutuhan fisik kita mengenai barang-barang dan bangunan yang bermanfaat (physical function of art) (1991:2).

\section{1).Fungsi Personal}

Fungsi personal seni dalam kebutuhan yaitu sebagai alat ekspresi individu. Bidang seni rupa dimanfaatkan oleh manusia sebagai medium dan wahana ekspresi atau alat komunikasi, karena seniman ingin eksistensi karyanya diterima oleh lingkungan. Seni menampilkan pandangan individual yang berasal dari objek-objek, fakta, kejadian-kejadian yang akrab dengan kehidupan manusia itu sendiri, dari tempat dimana ia hidup. Dapat dikatakan setiap karya seni berfungsi sebagai wadah ungkapan (ekspresi), namun peran ungkapan ini tidak mengurangi fungsi seni sebagai alat sosial dan sebagai benda estitik serta benda fisik. Seni kerajinan batik yang termasuk lingkup seni rupa adalah salah satu media tersebut (Nasbahry, 2002:5051).
Proses pembatikan yang tidak mudah dan membutuhkan ketekunan pada pembentukan motif hias, dibuat sedemikian detail, agar motif tetap menyerupai bentuk aslinya, pesan dan nilai yang terkandung dapat disampaikan kepada penikmat. Perajin batik sebagai seniman terlihat dari ketekunan dan kesabaran mereka dalam membuat kerajinan batik. Selain itu kepuasan akan rasa estetis perajin sebagai personal juga menuntut perajin mampu memuaskan kebutuhan estetis penikmat atau konsumen. Aspek estetis seorang seniman terlihat dari kemampuannya dalam menangkap hal-hal yang khas, unik dan istimewa dan mengabadikannya dalam bentuk karya seni, sehingga menarik perhatian pengamatnya. Sesuatu yang estetis termasuk konsepkonsep atau ide baru, maka perajin sekaligus seniman berusaha menciptakan semua produk batik seindah mungkin sekaligus bermanfaat.

\section{2).Fungsi Sosial}

Manusia sebagai makhluk sosial disamping mempunyai tanggungjawab atas dirinya, terikat pula oleh lingkungan sosialnya. Semua karya seni yang berkaitan dengannya akan berfungsi sosial karena karya seni diciptakan untuk penghayat. Tidak dapat dipungkiri bahwa seniman mengharapkan adanya sesuatu dari masyarakat peghayatnya. Apakah masyarakat akan menerimanya dengan rasa kagum dan menghargainya. Sebagai konsekuensinya, karya seni yang mereka ciptakan merupakan respon sosial dengan dorongan personal, sekaligus mempunyai fungsi sosial. Fungsi sosial seni menurut Feldman yaitu: 1) karya seni itu mencari atau cenderung mempengaruhi perilaku kolektif orang banyak, 2) karya itu diciptakan untuk dilihat atau dipakai (dipergunakan) khususnya dalam situasi-situasi umum, dan 3) karya seni itu mengekspresikan atau menjelaskan aspek-aspek tentang eksistensi sosial atau kolektif sebagai lawan dari bermacam-macam pengalaman personal maupun individu (1991: 61-62).

Jenis produk batik yang dihasilkan oleh para perajin adalah untuk pemenuhan kebutuhan hidup masyarakat. Diantaranya berupa produk pakaian, benda-benda fungsional, maupun barang-barang cenderamata. Fungsi seni yang digunakan pada situasi umum menurut Feldman merupakan produk yang digunakan pada acara-acara tertentu, seperti kepentingan upacara adat.

Batik diciptakan atas dasar penggunaan pada situasi umum serta menggambarkan aspek kelompok sebagai wujud adanya perbedaan pengalaman personal (Dharsono, 2004:33). Dapat dilihat dari bentuk ragam 


\section{Gorga Jurnal Seni Rupa \\ Volume 07 Nomor 02 \\ p-ISSN: 2301-5942 | e-ISSN: 2580-2380}

hias yang terdapat pada batik. Ragam hias pada batik Minang Nagari Panyakalan berfungsi untuk mengingatkan masyarakat Minangkabau akan nilainilai budaya yang terkandung di dalamnya. Corak yang terinspirasi dari alam selain berfungsi sebagai penghias juga mengandung makna simbolik yang berisi pesan-pesan kehidupan.

\section{3).Fungsi Fisik}

Fungsi berhubungan dengan penggunaan yang efektif sesuai dengan kriteria kegunaan dan efisiensi, baik penampilan maupun tuntutannya atau permintaannya (Feldman, 1991:128). Sejalan dengan pemikiran Nasbahry, bahwa fungsi fisik karya seni adalah beroperasinya objek-objek yang dibuat sesuai dengan tujuan tertentu (2002:63). Kerajinan batik memiliki fungsi fisik karena kegunaannya, antara wujud dan daya tarik penampilan suatu karya seni sangat diperlukan. Selain berfungsi sebagai nilai estetik, nilai simbol dan nilai kepraktisan karya yang dihasilkan, batik berfungsi sebagai produk kerajinan. Batik berupa kreasi yang secara fisik dapat digunakan untuk kebutuhan praktis sehari-hari, selain digunakan sebagai keperluan untuk kelengkapan pakaian pada upacara adat. Batik merupakan karya seni yang berorientasi pada kebutuhan fisik (fungsional) selain keindahannya yang harus tetap diutamakan.

Motif pada seni batik Minang Panyakalan memiliki fungsi sebagai pemenuhan unsur estetika sebuah karya, hal ini sesuai dengan pengertian ornamen itu sendiri yaitu sebagai hiasan yang dibuat pada arsitektur, kerajinan, perhiasan, dan sebagainya. Adanya penambahan motif pada batik Minang telah memberikan nilai estetika tersendiri bagi siapa saja yang memandangnya. Batik sebagai kegiatan yang produktif, dilakukan sebagian kecil masyarakat Panyakalan dengan menggunakan keterampilan tangan. Proses secara manual menghasilkan kain batik yang estetis, merupakan ekspresi kultur dari kreatifitas individual dan kolektif yang lahir dari kristalisasi pengalaman seniman, pengusaha dan perajin. Sistem produksi sudah menggunakan teknik cetak / cap.

\section{KESIMPULAN DAN SARAN}

Berdasarkan uraian yang telah dikemukakan tentang ragam hias dan fungsi batik Minang Nagari Panyakalan, motif yang terdapat pada kain bati Minang Panyakalam merujuk pada bentuk kekayaan alam yang ada di Kabupaten Solok. Seperti motif rumah gadang, motif batang padi dan motif markisa. Meski hadir motif baru tersebut, motif ragam hias Minangkabau tetap digunakan, seperti: motif kaluak paku, kacang balimbiang, pucuak rabuang, saik galamai, aka cino, sikambang manih, dan lain-lain. Adapun pewarnaan pada kain batik Minang ini tidak lagi menggunakan bahan alami seperti tanah liat dan dedaunan, melainkan telah menggunakan bahan kimia seperti proses pewarnaan batik pada umumnya di Indonesia.

Motif batik Minang berfungsi sebagai penghias dan penunjang penampilan pemakainya. Kehadiran motif atau ragam hias yang baru diciptakan telah memberikan nilai estetika tersendiri bagi siapa saja yang memandangnya. Selain itu juga memiliki fungsi personal bagi perajin, fungsi sosial bagi masyarakat, dan fungsi fisik pada kain batik Minang itu sendiri.

\section{DAFTAR RUJUKAN}

Anas Biranul. 1997. Indonesia Indah 8 Batik. Jakarta: Yayasan Harapan Kita/ BP 3- TMII.

Djumena, Nian S. 1990. Batik dan Mitra, Batik And Its Kind. Jakarta: Djambatan.

Felman, Edmund Burke. 1991. Art As Image And Idea. Terj. Sp. Gustami. Yogyakarta: Fakultas Seni Rupa dan Desain ISI Yogyakarta.

Gustami, SP. 2007. Butir-Butir Mutiara Estetika Timur: Ide Dasar Penciptaan Seni Kriya Indonesia. Yogyakarta: Prasista.

Hamidin, Aep S. 2010. Batik Warisan Budaya Asli Indonesia. Yogyakarta: Narasi.

Kartika, Dharsono Sonny. 2004. Seni Rupa Modern. Bandung: Rekayasa Sains.

Moleong, Lexy J. 2004. Metodologi Penelitian Kualitatif. Bandung: PT. Remaja Rosdakarya.

Muri, Yusuf. A. 2005. Metodologi Penelitian. Padang:

Nasbahry Couto dan Minarsih. 2002. Seni Rupa Teori Dan Aplikasinya. Padang: Universitas Negeri Padang.

Navis, AA. 1984. Alam Terkembang Jadi Guru. Jakarta: Grafiti Pers.

Sachari, Agus. 2002. Estetika Makna, Simbol dan Daya. Bandung: ITB.

SP. Soedarso. 2006. Trilogi Seni Penciptaan Eksistensi dan Kegunaan Seni. Yogyakarta: BP ISI Yogyakarta.

Sugiyono. 2008. Metode Penelitian Kuantitatif, Kualitatif dan R\&D. Bandung: Alfabeta.

Toekio, Soegeng. 1994. Mengenal Ragam Hias Indonesia. Bandung: Angkasa.

Yanuarmi, Dini. 2011. Seni Batik Tanah Liek di Painan Sumatera Barat: Kajian Estetik Melalui Analisis Sosiologis. Tesis Magister Seni ISI Padangpanjang: Padangpanjang. UNP Press. 